\title{
Bio-CNG: A Technology for Green House Gas Mitigation and Revenue Generation from Agro Waste
}

\author{
Rashmi Sahu $^{1 *}$, Mayuri Gupta ${ }^{2}$, Partha Sarathi Singha $^{1}$ and Saurajyoti Baishya ${ }^{1}$ \\ ${ }^{1}$ Department of Agricultural and Food Engineering, IIT Kharagpur, Kharagpur 721302, India \\ ${ }^{2}$ Barkatullah University Institute of Technology, Bhopal, 462026, India \\ *Corresponding author
}

\section{A B S T R A C T}

\begin{tabular}{l} 
K e y w o r d s \\
$\begin{array}{l}\text { Straw burning, } \\
\text { Nutrient, } \\
\text { hazardous effects }\end{array}$ \\
\hline Article Info \\
$\begin{array}{l}\text { Accepted: } \\
18 \text { May } 2020 \\
\text { Available Online: } \\
\text { 10 June } 2020\end{array}$ \\
\hline
\end{tabular}

Straw burning after harvesting is a current environmental issue causing loss of nutrient to soil and many hazardous effects to the environment. To overcome the problem of straw burning is Bio-CNG generation from agrowaste. Converting stubble into energy is an innovative way to address the matter as it helps to reduce the greenhouse effect and fight against the threats of global warming. The Bio-CNG is an ideal fuel for automobiles and its low emission levels also make it a more environment-friendly fuel than biogas and other fuels. Bio-CNG is much cheaper than other competitive fuels. Bio-CNG enhances the rural economy by imparting development in the available resources and employment generation.

\section{Introduction}

Farmers in many parts of the world set fire to cultivated fields to clear stubble, weeds and waste before sowing a new crop. While this practice may be fast and economical, it is highly unsustainable, as it produces large amounts of the particle pollutant black carbon and reduces the fertility of soil.

\section{Why do farmers burns crop residues in field?}

Increased mechanization,
Declining number of livestock,

Long period required for composting

No economically viable alternate use of residues

Time gap between kharif crop harvesting and wheat sowing is less 15-20 days

With combine harvesting about $80 \%$ of loose straw left in field \& finally being burnt in field. 


\section{Effect of crop burning}

The heat from burning paddy straw penetrates $1 \mathrm{~cm}$ into the soil, elevating the temperature to 33.8 to 42.2 degree Celsius. This kills the bacterial and fungal populations critical for a fertile soil.

Burning of crop residue causes damage to other micro-organisms present in the upper layer of the soil as well as its organic quality. Due to the loss of 'friendly' pests, the wrath of 'enemy' pests gets increased and as a result, crops are more prone to disease. The solubility capacity of the upper layers of soil has also been reduced.

According to a report, burning of one tonne of paddy straw leads to a loss of 5.5 kilogram nitrogen, $2.3 \mathrm{~kg}$ phosphorus, $25 \mathrm{~kg}$ potassium and more than $1 \mathrm{~kg}$ of sulfur all soil nutrients, besides organic carbon.

About $90 \%$ of $\mathrm{N}$ and $\mathrm{S}$ and $15-20 \%$ of $\mathrm{P}$ and $\mathrm{K}$ contained in rice residue are lost during burning. Burning of 23 million tonnes of rice residues in NW India leads to a loss of about 9.2 million tonnes of $\mathrm{C}$ equivalent $(\mathrm{CO} 2-$ equivalent of about 34 million tonnes) per year and a loss of about $1.4 \times 105 \mathrm{t}$ of $\mathrm{N}$ (equivalent to Rs 200 crores) annually.

Mitigation approaches for management of biomass

Crop residue management through soil incorporation and mulching (In-situ)

Straw Mulch

Residue incorporation

\section{Crop residue management through energy generation (Ex-situ)}

Commercially available technologies for exsitu treatment such as solid fuel (pelletisation, and briquetting), gaseous fuel (Bio-CNG and producer gas) and liquid fuel (ethanol and bio-oil) are assessed. This article will discuss Bio-CNG only.

\section{Why Bio-CNG?}

Compressed biogas is exactly similar to the commercially available natural gas in its composition and energy potential. Given the abundance of biomass in the country, compressed biogas has the potential to replace CNG in automotive, industrial and commercial uses in the coming years. Bio$\mathrm{CNG}$ also holds great promise for efficient municipal solid waste management and in tackling the problem of polluted urban air due to farm stubble-burning and carbon emissions. The Bio-CNG process also produces enriched organic manure which can be used as fertilizer.

There is large potential of this technology in buses, tractors, cars, auto rickshaws, irrigation pump sets and in rural industries. This will help to meet our energy demand for rural masses thus reduces burden of petroleum demand, moves towards energy security and will improve economic status by creating employment generation in rural area.

\section{Bio-CNG: an alternative fuel}

Bio-gas is produced naturally through a process of anaerobic decomposition from waste / bio-mass sources like agriculture residue, cattle dung, sugarcane press mud, municipal solid waste, sewage treatment plant waste, etc. After purification, it is compressed and called $\mathrm{CBG} / \mathrm{Bio}-\mathrm{CNG}$, which has pure methane content of over $95 \%$.

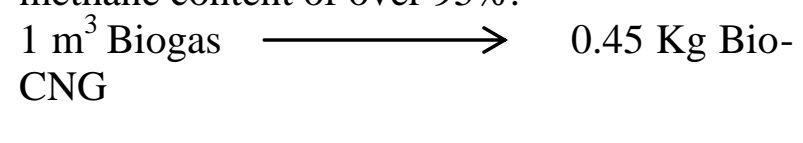

Bio-CNG is a clean, low carbon technology for efficient management and conversion of 
fermentable organic wastes into clean, cheap $\&$ versatile fuel and bio/organic manure. Potential of Bio-CNG is not being utilized and commercialized so far, which could provide three in one solution of gaseous fuel generation like cooling gas, fuel gas \& electricity. Also it provides a benefit of proper bio-degradable waste management along with organic manure as a by-product.

The high methane content and calorific value combined with less moisture content and low concentrations of impurities like hydrogen sulphide makes the Bio-CNG an ideal fuel for automobiles and power generation. The low emission levels of Bio-CNG also make it a more environment-friendly fuel than biogas. There are multiple benefits from converting agricultural residue, cattle dung and municipal solid waste into Bio-CNG on a commercial scale:

Responsible waste management, reduction in carbon emissions and pollution

Additional revenue source for farmers

Boost to entrepreneurship, rural economy and employment

Support to national commitments in achieving climate change goals

Reduction in import of natural gas and crude oil

Buffer against crude oil/gas price fluctuations

Bio-CNG has a high calorific value and can be used in blast furnaces also it can be converted into electricity.

\section{Production process}

Bio-CNG is produced in the four main steps mentioned below

\section{Extraction}

Bio-gas is produced naturally through a process of anaerobic decomposition from waste / bio-mass sources like agriculture residue, cattle dung, sugarcane press mud, municipal solid waste, sewage treatment plant waste, etc.This biogas is a mixture of methane $\left(\mathrm{CH}_{4}\right)$, carbon dioxide $\left(\mathrm{CO}_{2}\right)$, and hydrogen sulphide $\left(\mathrm{H}_{2} \mathrm{~S}\right)$.

\section{Purifcation}

The next phase in the process is to purify the biogas generated from the anaerobic decomposition of straw to get highly purified biomethane. Removal of $\mathrm{CO}_{2}$ (carbon dioxide) and $\mathrm{H}_{2} \mathrm{~S}$ (hydrogen sulfide) from biogas needs to be done to improve the quality of the biogas in the fuel.

The presence of $\mathrm{H}_{2} \mathrm{~S}$ in biogas can lead to corrosion of the equipment, in addition to this, $\mathrm{H}_{2} \mathrm{~S}$ is also dangerous for human and animal health. $\mathrm{CO}_{2}$ content in biogas also has corrosive effect, therefore it should also be treated as an impurity, so the purification process needs to be done in order to qualify biogas as natural gas which is environment friendly and safe for health.

\section{Biogas purification technologies}

Scrubbing

Chemical Absorption

Pressure Swing Adsorption

Membrane Purification

Cryogenic Separation

Biological Processes

\section{Pressurizing and storage}

The purified biomethane so produced is then pressurized and filled in high-pressure cylinders.

\section{Dispersion}

The Bio CNG, so collected, is now ready to be dispensed for use in two wheelers, autos, cars, as well as trucks and tractor. 


\section{Commercial aspect}

The economical evaluation of Bio-CNG production is assessed. It shows that the cost of $1 \mathrm{~kg}$ of bio-CNG is Rs. 25-35. Bio-CNG is much cheaper than CNG and other fuels, as the production cost of Bio-CNG is 20-50 percent lower than the other fuels like CNG and other petroleum products. Bio-CNG can be considered as the most efficient fuel that can replace the currently available gaseous and petroleum fuels.

Table.1

\begin{tabular}{|l|c|c|}
\hline Parameters & Biogas & Bio-CNG \\
\hline Methane (v/v) & $55-65 \%$ & $92-98 \%$ \\
\hline CO2 (v/v) & $35-45 \%$ & $2-8 \%$ \\
\hline H2 S (ppm) & $500-30,000 \mathrm{ppm}$ & $<20 \mathrm{ppm}$ \\
\hline Calorific Value (LCV) & $\sim 19500 \mathrm{~kJ} / \mathrm{kg}$ & $\sim 52000 \mathrm{~kJ} / \mathrm{kg}$ \\
\hline
\end{tabular}

Table.2

\begin{tabular}{|c|l|c|}
\hline \multicolumn{2}{|l|}{ Capacity of BioCNG plant kg/day } & $\mathbf{5 0 0}$ \\
\hline Assumptions & \multicolumn{1}{l|}{} \\
\hline $\mathbf{1}$ & Straw required (kg) to produce 1 kg biocng & 22000000 \\
\hline $\mathbf{2}$ & Total cost of plant Rs. & 50 \\
\hline $\mathbf{3}$ & Sale price of biocng Rs./kg & 4 \\
\hline $\mathbf{4}$ & Sale price of bio manuare Rs./kg & 3000 \\
\hline & Manure production kg/day & 15 \\
\hline $\mathbf{5}$ & Life of plant year & 2 \\
\hline $\mathbf{6}$ & Land Requirement (Acres) & \\
\hline Estimated cost of plant & 10000000 \\
\hline $\mathbf{1}$ & Biogas plant (CSTR)Rs. & 3000000 \\
\hline $\mathbf{2}$ & Biogas purification cost Rs. & 2000000 \\
\hline $\mathbf{3}$ & Biogas compression cost Rs. & 3500000 \\
\hline $\mathbf{4}$ & Storage cost Rs. & 1500000 \\
\hline $\mathbf{5}$ & Miscellaneous cost Rs. & 2000000 \\
\hline $\mathbf{6}$ & Land Preparation \& Other Civil Work & $15-20$ \\
\hline Total operational cost Rs./ kg-day & $25-35$ \\
\hline Total cost of production of Bio-CNG Rs./kg & $\mathbf{2 . 5 - 3 ~ y e a r ~}$ \\
\hline Payback period &
\end{tabular}




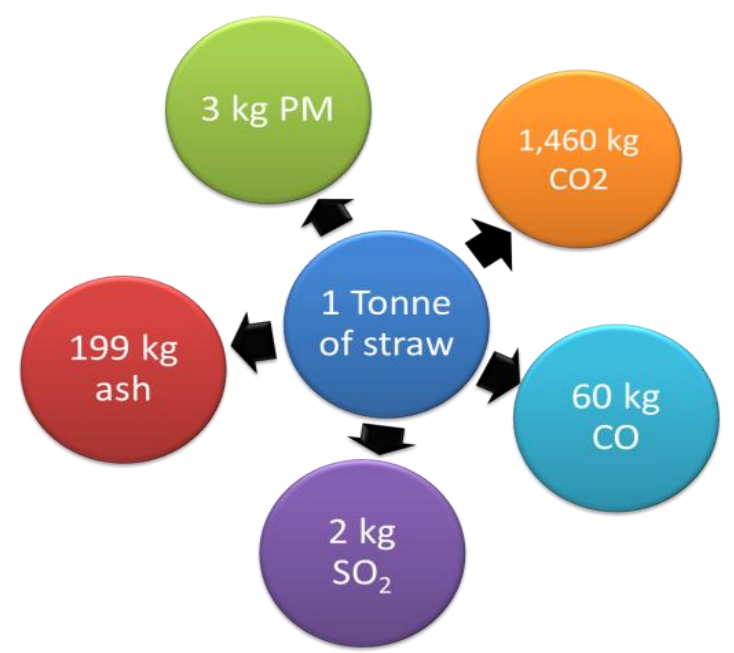

Fig.1 One tonne of straw burning releases

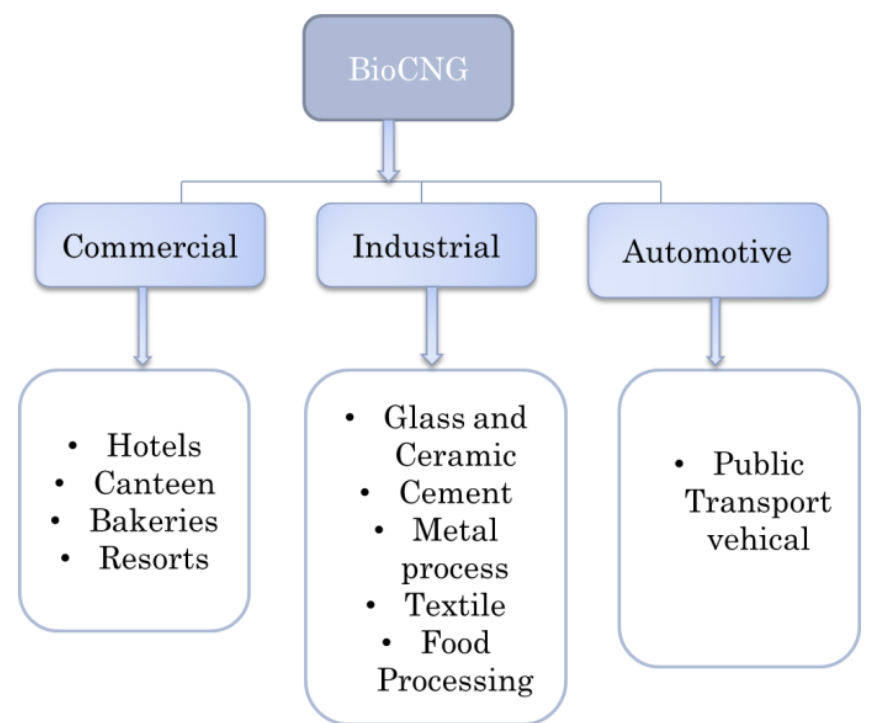

Fig.2

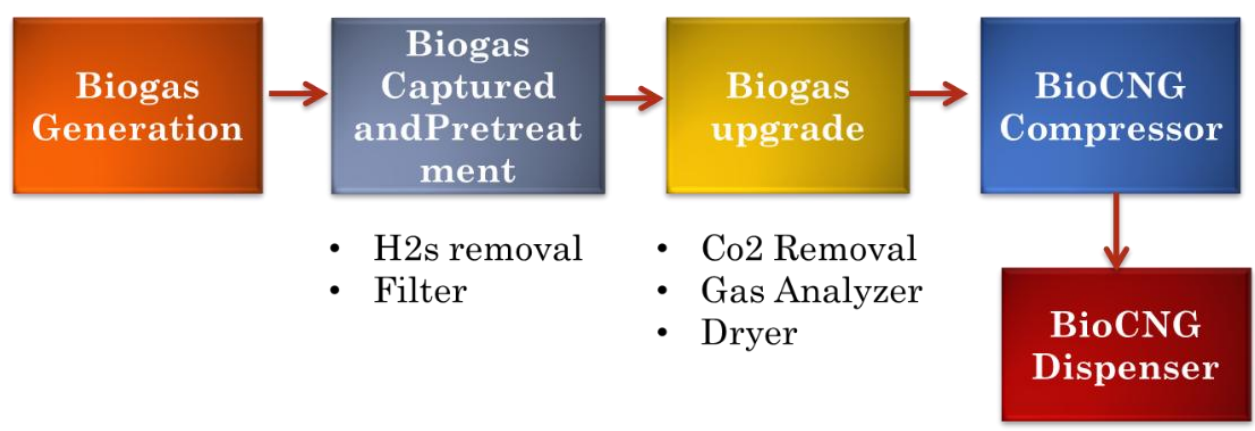

- High flow dispensor

- Trailer refilling

- Pressure 250 bar

Fig.3 
Therefore, it is clearly depicted that Bio-CNG is a rising candidate for automobile fuel. Although Bio-CNG has several advantages over the conventional vehicle fuel, India is facing a big problem of solid waste management that can also be managed properly. Bio-CNG ultimately reduce carbon footprints and producing sufficient fuels like cooking fuel, vehicle fuel and electricity, it will upgrade the quality of living of rural India.

\section{References}

Annual report on Indian Petroleum \& Natural Gas Statistics 2018-19, Ministry of Petroleum and Natural Gas,m2019.

EAI, 2009. Biomethanation in India - Biogas potential, trends and prospects posted by Energy Alternatives India.
Hiloidhari, M., Das, D. and Baruah, D.C. 2014. Bioenergy potential from crop residue biomass in India. Renewable and sustainable energy reviews, 32, 504-512.

https://renewablewatch.in/2018/08/19/biogasbio-cng/

https://renewablewatch.in/2018/12/25/paddypower/

R.Manoj Kumar., 2018 "India's Bio CNG: Challenges and Opportunities .IOSR Journal of Mechanical and Civil Engineering (IOSR-JMCE) , 15, 43-4

Rupnar A.K., Jain S and Panwar N.L. 2018. Biogas in India: Potential and Integration into Present Energy Systems. International Journal of Current Microbiology and Applied Sciences, 7, 2175-2186.

\section{How to cite this article:}

Rashmi Sahu, Mayuri Gupta, Partha Sarathi Singha and Saurajyoti Baishya. 2020. Bio-CNG: A Technology for Green House Gas Mitigation and Revenue Generation from Agro Waste. Int.J.Curr.Microbiol.App.Sci. 9(06): 2146-2151. doi: https://doi.org/10.20546/ijcmas.2020.906.262 